\title{
Leuconostoc inhae sp. nov., a lactic acid bacterium isolated from kimchi
}

\author{
Bongjoon Kim, Jongho Lee, Jichan Jang, Jeongho Kim and Hongui Han
}

Correspondence

Hongui Han

biohan@inha.ac.kr
Research Laboratory for Microbiology, Department of Biological Sciences, Inha University, Incheon 402-751, Republic of Korea

\begin{abstract}
Six strains of a hitherto unknown bacterium isolated from kimchi, a fermented vegetable food produced in Korea, were characterized by using phenotypic methods, phylogenetic analysis and DNA-DNA hybridization. The novel strains were Gram-positive, non-spore-forming, heterofermentative and spherical or lenticular lactic acid bacteria. Comparative 16S rRNA gene sequencing and DNA relatedness demonstrated that the unknown strains represented a novel clade within the genus Leuconostoc and were close to, but distinct from, Leuconostoc gelidum. The unknown strains were clearly distinguished from all described members of the genus Leuconostoc by using RFLP patterns of genus-specific 16S rRNA gene PCR products with a single endonuclease, BsmAl. Based on the polyphasic evidence, the unknown isolates are classified as Leuconostoc inhae sp. nov. The type strain is strain $\mathrm{IHOO}^{\top}\left(=\mathrm{KCTC} 3774^{\top}=\mathrm{DSM} 15101^{\top}\right)$.
\end{abstract}

Kimchi is a traditional Korean food prepared from various vegetables and consumed as a main side dish. It is kept in a cryogenic storage system for between 2 weeks and 4 months, thereby allowing leuconostocs to predominate in the whole fermentation. We have been focusing on the diversity of species and, at present, five Leuconostoc species have been isolated from kimchi: Leuconostoc gelidum, Leuconostoc mesenteroides, Leuconostoc citreum (Kim et al., 2000a), Leuconostoc kimchii (Kim et al., 2000b) and dextranproducing Leuconostoc lactis (Kim et al., 2001). As a part of a study of the microflora of kimchi, we have isolated six strains that fall into a group distinct from all known members of the genus Leuconostoc (Garvie, 1986; Shaw \& Harding, 1989; Farrow et al., 1989; Martinez-Murcia \& Collins, 1991; Dicks et al., 1993; Björkroth et al., 2000; Kim et al., 2000b; Antunes et al., 2002), but are closely related to L. gelidum. In this article, we report the characterization of these unknown lactic acid bacteria and the results of a polyphasic taxonomy study. Based on the results, a novel species is described, Leuconostoc inhae sp. nov.

Six strains, IH003 ${ }^{\mathrm{T}}$, IH101, IH201, IH316, IH515 and IH611, were isolated from kimchi fermented for 18 days at $5-8{ }^{\circ} \mathrm{C}$. These unknown strains were cultured with 14 Leuconostoc and one Weissella species as reference type strains at $25^{\circ} \mathrm{C}$ on MRS agar (Difco) or in broth. The morphology of isolates was examined by using scanning electron microscopy (S-4200; Hitachi). Additional

Published online ahead of print on 13 December 2002 as DOI 10.1099/ijs.0.02463-0.

The GenBank/EMBL/DDBJ accession numbers for the 16S rRNA gene sequences of strains $\mathrm{HHOO}^{\top}$ and $\mathrm{H} \mathrm{H} 611$ are $\mathrm{AF} 439560$ and AY117686. biochemical and physiological tests were performed according to the methods of Smibert \& Krieg (1994) and Garvie (1984). Growth at different temperatures and $\mathrm{pH}$ and tolerance of $\mathrm{NaCl}$ were tested in MRS broth. Carbohydrate fermentation patterns were determined at $25^{\circ} \mathrm{C}$ by using API CH50 strips and the API CHL medium system according to the manufacturer's instruction (bioMérieux). The optical isomer of lactic acid was determined by using a D-/L-lactate dehydrogenase kit (TC D-/L-lactic acid; Boehringer Mannheim).

Sequencing of $16 \mathrm{~S}$ rDNA was carried out as described by Kim et al. (2000b). The 16S rDNA sequences of isolates were aligned by using CLUSTAL X software (version 1.8). Similarity values were calculated using SIMILARITY MATRIX (version 1.1) in RDP-II (Maidak et al., 2001). Calculation of an evolutionary distance matrix (Kimura two-parameter model), construction of a neighbour-joining phylogenetic tree and bootstrap analysis (1000 replicates) were carried out by using PHYLIP (Felsenstein, 1993). DNA-DNA hybridization was performed as described by Kim et al. (2000b), using the protocol described in the ECL direct nucleic acid labelling and detection system (RPN 3000; Amersham Pharmacia Biotech). $\mathrm{G}+\mathrm{C}$ contents were determined by HPLC as described by Tamaoka \& Komagata (1984).

Differentiation of Leuconostoc species was carried out by the method described by Jang (2002). For the detection of Leuconostoc species, the following genus-specific primers were used to amplify $16 \mathrm{~S}$ rRNA genes: forward primer $5^{\prime}$ CGAAAGGTGCTTGCACCTTTCAAG-3' (Escherichia coli numbering system, positions 74-98); reverse primer $5^{\prime}$ TTTGTCTCCGAAGAGAACA-3' (positions 1023-1040). 
These primers produced a 976 bp PCR fragment. PCR amplification was carried out with the method described by Kim et al. (2000b). For species identification, restriction fragment length polymorphism (RFLP) analysis of PCR products (976 bp) was performed with four endonucleases, MseI, HaeIII, Tsp509I and BsmAI (New England Biolabs). Digestions were performed at 37 (MseI, HaeIII), 55 (BsmAI) or 65 (Tsp509I) ${ }^{\circ} \mathrm{C}$ according to the manufacturer's instructions.

Cellular morphology of the six isolates was spherical or lenticular, showing the shape typical of members of the genus Leuconostoc (Garvie, 1986). Cells of a representative strain $\mathrm{IH}_{003^{\mathrm{T}}}$ are shown in Fig. 1. They were Gram-positive, catalase-negative, arginine dihydrolase-negative and produced gas and over $92 \%$ D-lactic acid from glucose. They grew at $\mathrm{pH} 4.8$ and in $3 \% \mathrm{NaCl}$ and at 1,5 and $30{ }^{\circ} \mathrm{C}$ but not at $37^{\circ} \mathrm{C}$. Dextran production from $5 \%$ sucrose agar medium was variable $(\sim 50 \%)$. Cellular morphology and general biochemical characteristics of the isolates were consistent with their assignment to the genus Leuconostoc (Garvie, 1986). The details are presented in Table 1 and in the species description below.

The 16S rRNA genes of $1 \mathrm{H} 003^{\mathrm{T}}$ and IH611 were sequenced and subjected to a comparative analysis to establish the phylogenetic relationship of the isolates. The almost-complete gene sequences (1474 and $1505 \mathrm{nt}$ ) were determined and found to be identical. Sequence database searches showed that the sequence similarity of $\mathrm{IH} 003^{\mathrm{T}}$ and $\mathrm{IH} 611$ was $99 \cdot 1$ and $98.9 \%$ to L. gelidum DSM $5578^{\mathrm{T}}$. The phylogenetic position of these isolates within the genus Leuconostoc is presented in Fig. 2. The isolates were most closely related to, but different from, L. gelidum DSM $5578^{\mathrm{T}}$, and constituted a 'cold cluster' with L. kimchii KCTC $2386^{\mathrm{T}}$, Leuconostoc carnosum DSM $5576^{\mathrm{T}}$, Leuconostoc gasicomitatum LMG $18811^{\mathrm{T}}$ and L. gelidum DSM $5578^{\mathrm{T}}$, frequently isolated at low temperatures (Shaw \& Harding, 1989; Kim et al., 2000b; Björkroth et al., 2000). The mean G $+\mathrm{C}$ content of the six isolates was $39 \cdot 9 \pm 0 \cdot 5 \mathrm{~mol} \%$. This value is within a range

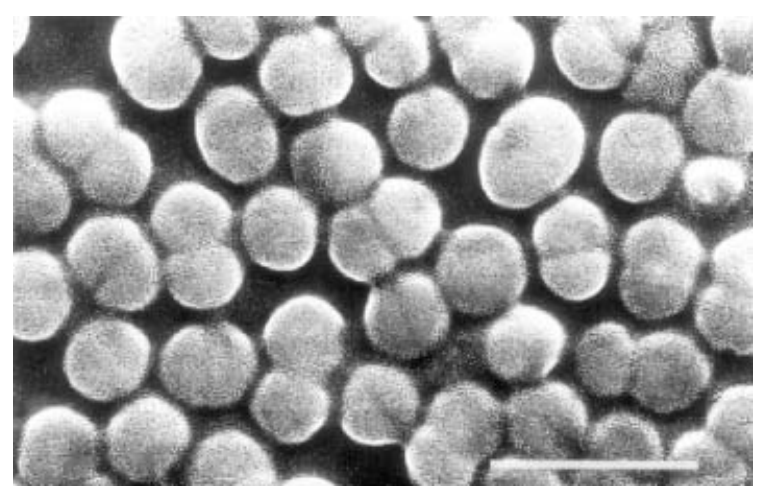

Fig. 1. Scanning electron micrograph of Leuconostoc inhae sp. nov. $\mathrm{IHOO}^{\top}$. Cells were grown in MRS medium at $25^{\circ} \mathrm{C}$ for 24 h. Bar, $2 \mu \mathrm{m}$.
Table 1. Differential characteristics of Leuconostoc inhae sp. nov. and related leuconostocs

Species/strains: 1, L. inhae sp. nov. ( $n=6$; data from this study); 2, L. gelidum DSM $5578^{\mathrm{T}}$ (data from Shaw \& Harding, 1989); 3, L. carnosum DSM 5576 ${ }^{\mathrm{T}}$ (Shaw \& Harding, 1989); 4, L. gasicomitatum LMG $18811^{\mathrm{T}}$ (Björkroth et al., 2000); 5, L. kimchii KCTC $2386^{\mathrm{T}}$ (Kim et al., 2000b). Results are scored as:,$+ \geqslant 90 \%$ strains positive;,$- \geqslant 90 \%$ strains negative; d, $11-89 \%$ strains positive (number of strains positive is shown). All strains/species showed the following results for acid production: positive for D-fructose, D-glucose, D-mannose, methyl $\alpha$-D-glucoside, ribose, sucrose and trehalose; negative for D-arabinose, dulcitol, erythritol, glycerol, melezitose, rhamnose, sorbitol and L-sorbose. Other characteristics are mentioned in the species description.

\begin{tabular}{|lccccc|}
\hline Acid produced from: & $\mathbf{1}$ & $\mathbf{2}$ & $\mathbf{3}$ & $\mathbf{4}$ & $\mathbf{5}$ \\
\hline Amygdalin & $\mathrm{d}(3 / 6)$ & + & - & - & + \\
L-Arabinose & + & + & - & + & + \\
Arbutin & - & + & - & - & - \\
Cellobiose & + & + & - & + & + \\
Galactose & $\mathrm{d}(3 / 6)$ & - & - & + & + \\
Gluconate & $\mathrm{d}(3 / 6)$ & - & - & + & + \\
Lactose & - & - & - & - & + \\
Mannitol & + & - & - & - & + \\
Maltose & + & - & - & + & + \\
Melibiose & - & + & - & + & - \\
Raffinose & - & + & - & + & - \\
Salicin & $\mathrm{d}(3 / 6)$ & + & - & - & + \\
D-Xylose & - & + & - & + & - \\
\hline
\end{tabular}

for members of the genus Leuconostoc (38-44 mol\%; Garvie, 1986). The isolates showed more than $73 \%$ DNA relatedness to each other but less than $26 \%$ to all reference strains used (Table 2). Thus, the isolates were considered to represent a novel species belonging to Leuconostoc.

However, the separation of the isolates from L. gelidum was not definite, since they formed a phylogenetically close branch and had high sequence similarity, as mentioned above. We applied a PCR-RFLP method (Jang, 2002) by using a set of Leuconostoc genus-specific primers present in the 16S rRNA gene. The resultant PCR products were subjected to cascade digestion with three restriction enzymes, MseI, HaeIII and Tsp509I, yielding different combined PCR-RFLP patterns and enabling not only their detection but also identification at the genus and species level. Jang (2002) demonstrated that all described members of the genus Leuconostoc were successfully distinguished by RFLP patterns, excluding phylogenetically quite distant species such as Leuconostoc fallax, Leuconostoc ficulneum and Leuconostoc fructosum (Antunes et al., 2002; MartinezMurcia \& Collins, 1991). Nevertheless, our isolates could not be differentiated with these enzymes, since they showed identical RFLP patterns to L. gelidum DSM $5578^{\mathrm{T}}$ (data not shown). BsmAI was chosen theoretically from a highly variable region of the $16 \mathrm{~S}$ rRNA gene (positions 183-207) to 


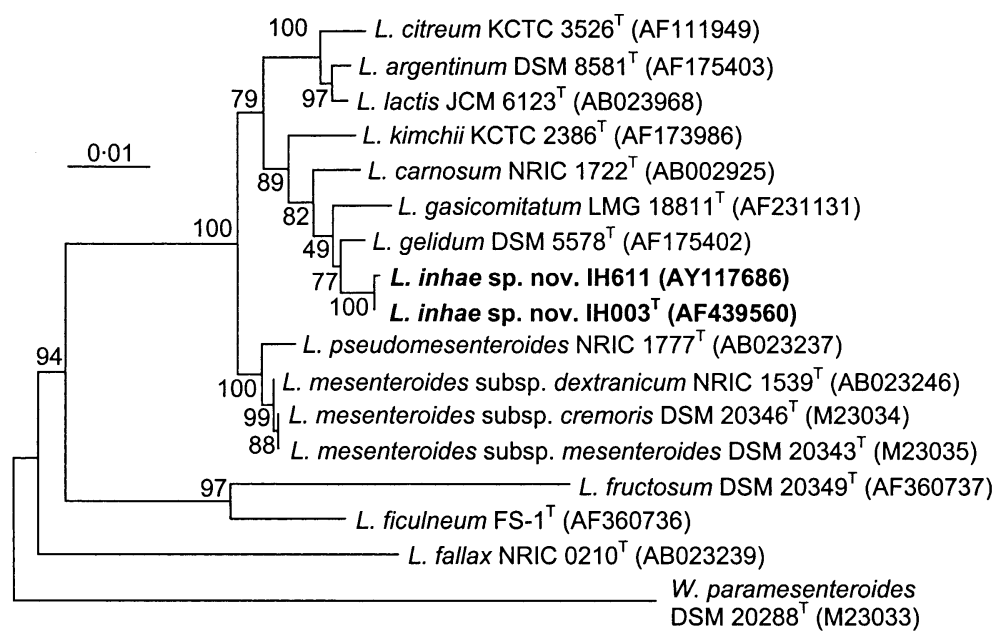

Fig. 2. Unrooted phylogenetic tree based on $16 \mathrm{~S}$ rDNA comparisons showing the relationships of $L$. inhae sp. nov. $\mathrm{HHOO}^{\top}$ and $\mathrm{IH} 611$ to other Leuconostoc strains. Bootstrap percentages obtained with 1000 resamplings are given at branch points. Accession numbers are given in parentheses. Bar, genetic distance of 0.01 . allow separation between the novel isolates and L. gelidum DSM $5578^{\mathrm{T}}$ by using WWWtacg version 2.38 (http:// genzi.virus.kyoto-u.ac.jp/tacg2/tacg2.form.html). Experimental RFLP patterns are shown in Fig. 3. L. kimchii KCTC $2386^{\mathrm{T}}$, L. carnosum DSM 5576 ${ }^{\mathrm{T}}$, L. gasicomitatum LMG $18811^{\mathrm{T}}$ and L. gelidum DSM $5578^{\mathrm{T}}$ (a 'cold cluster') revealed identical RFLP patterns (fragment sizes 232 and $711 \mathrm{bp}$ ), but the pattern differed from that of the six novel isolates (fragment sizes 107, 125 and $711 \mathrm{bp}$ ). Interestingly, RFLP patterns with BsmAI appeared to be identical in all Leuconostoc species with the exception of the novel isolates (data not shown). This indicates that the isolates can be differentiated independently with a single restriction enzyme, BsmAI, without using three enzymes as suggested above. PCR-RFLP analyses confirmed the phylogenetic homogeneity of the six isolates and their separation from other species of the genus Leuconostoc. These results are also supported by RFLP as a good distinct method for strain characterization (Heyndrickx et al., 1996). Thus, based on evidence from cellular morphology, phylogenetic analysis, DNA relatedness and PCR-RFLP patterns and their distinctive biochemical characteristics, the six isolates from kimchi are assigned to the genus Leuconostoc as Leuconostoc inhae sp. nov.

\section{Description of Leuconostoc inhae sp. nov.}

Leuconostoc inhae (in'ha.e. N.L. gen. n. inhae of Inha, from the Inha University, Republic of Korea).

Cells are Gram-positive, spherical or lenticular, occurring singly or in pairs. Cells are $0 \cdot 8-1 \cdot 0 \times 0 \cdot 8-1 \cdot 8 \mu \mathrm{m}$. Colonies on MRS agar after $48 \mathrm{~h}$ at $25^{\circ} \mathrm{C}$ are small $(1 \cdot 0-1 \cdot 5 \mathrm{~mm})$, round, smooth, convex, opaque and greyish-white. Cells are non-motile and non-spore-forming. Facultatively anaerobic. Catalase-negative. Obligately heterofermentative. Arginine is not hydrolysed. Some strains produce slime

Table 2. Levels of DNA relatedness among $L$. inhae sp. nov. and Leuconostoc species within the same cluster

Percentage reassociation is shown. Reassociation values are means of duplicate determinations.

\begin{tabular}{|c|c|c|}
\hline \multirow[t]{2}{*}{ Source of unlabelled DNA } & \multicolumn{2}{|c|}{ Source of labelled DNA } \\
\hline & L. inhae $\mathrm{IH} 003^{\mathrm{T}}$ & L. gelidum DSM $5578^{\mathrm{T}}$ \\
\hline \multicolumn{3}{|l|}{ L. inhae } \\
\hline $\mathrm{IH}_{003}{ }^{\mathrm{T}}$ & 100 & 11 \\
\hline IH101 & 78 & 22 \\
\hline IH201 & 99 & 19 \\
\hline IH316 & 89 & 10 \\
\hline IH515 & 73 & 12 \\
\hline IH611 & 120 & 16 \\
\hline L. carnosum DSM $5576^{\mathrm{T}}$ & 20 & 2 \\
\hline L. gasicomitatum LMG $18811^{\mathrm{T}}$ & 20 & 6 \\
\hline \multicolumn{3}{|l|}{ L. gelidum } \\
\hline DSM $5578^{\mathrm{T}}$ & 26 & 100 \\
\hline IH619 & 25 & 97 \\
\hline L. kimchii KCTC $2386^{\mathrm{T}}$ & 23 & 4 \\
\hline
\end{tabular}




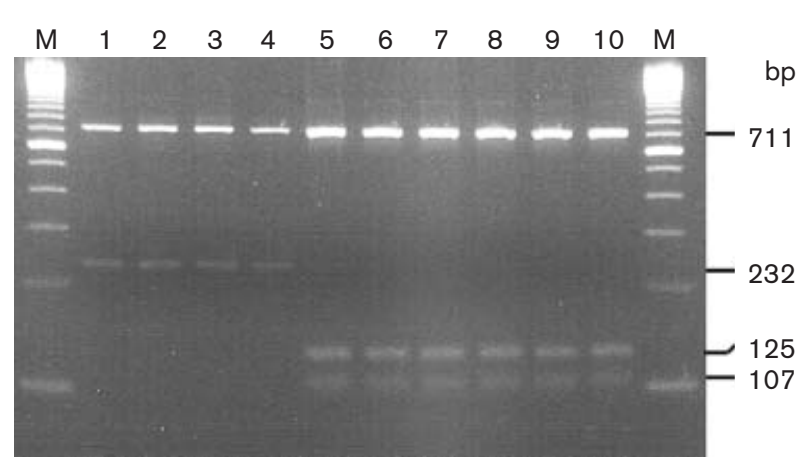

Fig. 3. PCR-RFLP patterns of $L$. inhae sp. nov. and closely related species derived from digestion of genus-specific PCR products with BsmAl. Lanes: 1 , L. carnosum DSM 5576 ${ }^{\top} ; 2$, L. gasicomitatum LMG $18811^{\top}$; 3, L. gelidum DSM 5578 ${ }^{\top}$; 4, L. kimchii KCTC $2386^{\top}$; 5-10, L. inhae sp. nov. $\mathrm{IH}_{003}{ }^{\top}, \mathrm{IH} 101, \mathrm{H} 201$, $\mathrm{IH} 316, \mathrm{IH} 515$ and IH611; M, 100 bp DNA ladder. RFLP patterns with BsmAl were identical in all strains of Leuconostoc examined except $L$. inhae strains and the phylogenetically distant strains L. fallax DSM $20189^{\top}$, L. ficulneum DSM $13613^{\top}$ and L. fructosum DSM $20349^{\top}$ (not shown). Only four species in the same cluster as $L$. inhae sp. nov. are shown.

materials. Growth occurs in $3 \% \mathrm{NaCl}$ but not in $7 \% \mathrm{NaCl}$ and at $\mathrm{pH} 4 \cdot 8$ but not at $\mathrm{pH} 3 \cdot 8$. All strains grow at $30{ }^{\circ} \mathrm{C}$ but not at $37^{\circ} \mathrm{C}$. Good growth is obtained at $1-5^{\circ} \mathrm{C}$. Over $92 \%$ D-lactic acid is produced from glucose. Acid is produced from L-arabinose, cellobiose, aesculin, D-fructose, $\beta$-gentiobiose, D-glucose, D-mannose, mannitol, maltose, methyl $\alpha$-D-glucoside, $N$-acetylglucosamine, ribose, sucrose and trehalose. Acid is not produced from adonitol, D-arabinose, D-arabitol, arbutin, 2-ketogluconate, 5ketogluconate, dulcitol, erythritol, D-fucose, L-fucose, glycerol, glycogen, inositol, inulin, lactose, D-lyxose, melezitose, melibiose, methyl $\alpha$-D-mannoside, methyl $\beta$-xyloside, D-raffinose, rhamnose, sorbitol, L-sorbose, starch, D-tagatose, xylitol, D-xylose or L-xylose. Some strains produce acid from amygdalin, galactose, gluconate, salicin and D-turanose. The $\mathrm{G}+\mathrm{C}$ content of the type strain is $39 \cdot 9 \pm 0 \cdot 5 \mathrm{~mol} \%$ (as determined by HPLC).

The type strain, strain $\mathrm{IH} 003^{\mathrm{T}}\left(=\mathrm{KCTC} 3774^{\mathrm{T}}=\mathrm{DSM}\right.$ $15101^{\mathrm{T}}$ ), was isolated from kimchi. The description of the type strain corresponds to that of five other isolates, except that no growth occurs at $\mathrm{pH} 3.8$ and slime material is not produced from sucrose. Amygdalin, galactose, gluconate, salicin and D-turanose are not fermented.

\section{Acknowledgements}

Microbia Co. Ltd supported this study. The authors are indebted to Dr J. P. Euzéby and Professor J. Chun for their kind help in the denomination of the novel species. We also thank Dr J.-H. Yoon (Korea Research Institute of Bioscience and Biotechnology) for helping with DNA base composition analysis.

\section{References}

Antunes, A., Rainey, F. A., Nobre, M. F., Schumann, P., Ferreira, A. M., Ramos, A., Santos, H. \& da Costa, M. S. (2002). Leuconostoc ficulneum sp. nov., a novel lactic acid bacterium isolated from a ripe fig, and reclassification of Lactobacillus fructosus as Leuconostoc fructosum comb. nov. Int J Syst Evol Microbiol 52, 647-655.

Björkroth, K. J., Geisen, R., Schillinger, U., Weiss, N., De Vos, P., Holzapfel, W. H., Korkeala, H. J. \& Vandamme, P. (2000). Characterization of Leuconostoc gasicomitatum sp. nov., associated with spoiled raw tomato-marinated broiler meat strips packaged under modified-atmosphere conditions. Appl Environ Microbiol 66, 3764-3772.

Dicks, L. M. T., Fantuzzi, L., Gonzalez, F. C., Du Toit, M. \& Dellaglio, F. (1993). Leuconostoc argentinum sp. nov., isolated from Argentine raw milk. Int J Syst Bacteriol 43, 347-351.

Farrow, J. A. E., Facklam, R. R. \& Collins, M. D. (1989). Nucleic acid homologies of some vancomycin-resistant leuconostocs and description of Leuconostoc citreum sp. nov. and Leuconostoc pseudomesenteroides sp. nov. Int J Syst Bacteriol 39, 279-283.

Felsenstein, J. (1993). PHYLIP (phylogeny inference package) version 3.5c. Distributed by the author. Department of Genetics, University of Washington, Seattle, USA.

Garvie, E. I. (1984). Separation of species of the genus Leuconostoc and differentiation of the leuconostocs from other lactic acid bacteria. Methods Microbiol 16, 147-178.

Garvie, E. I. (1986). Genus Leuconostoc van Tieghem 1878. In Bergey's Manual of Systematic Bacteriology, vol. 2, pp. 1071-1075. Edited by P. H. A. Sneath, N. S. Mair, M. E. Sharpe \& J. G. Holt. Baltimore: Williams \& Wilkins.

Heyndrickx, M., Vauterin, L., Vandamme, P., Kersters, K. \& De Vos, P. (1996). Applicability of combined amplified ribosomal DNA restriction analysis (ARDRA) patterns in bacterial phylogeny and taxonomy. J Microbiol Methods 26, 247-259.

Jang, J. (2002). Development of $16 S$ rDNA PCR-RFLP for identification of Leuconostoc and Weissella species. MS thesis, Inha University, Incheon, Republic of Korea.

Kim, B.-J., Lee, H.-J., Park, S.-Y., Kim, J. \& Han, H.-U. (2000a). Identification and characterization of Leuconostoc gelidum, isolated from kimchi, a fermented cabbage product. Korean J Microbiol 38, 132-136.

Kim, J., Chun, J. \& Han, H.-U. (2000b). Leuconostoc kimchii sp. nov., a new species from kimchi. Int J Syst Evol Microbiol 50, 1915-1919.

Kim, B.-J., Min, B.-H., Kim, J. \& Han, H.-U. (2001). Isolation of dextran-producing Leuconostoc lactis from kimchi. Korean J Microbiol 39, 11-16.

Maidak, B. L., Cole, J. R., Lilburn, T. G. \& 7 other authors (2001). The RDP-II (Ribosomal Database Project). Nucleic Acids Res 29, 173-174.

Martinez-Murcia, A. J. \& Collins, M. D. (1991). A phylogenetic analysis of an atypical leuconostoc: description of Leuconostoc fallax sp. nov. FEMS Microbiol Lett 82, 55-60.

Shaw, B. G. \& Harding, C. D. (1989). Leuconostoc gelidum sp. nov. and Leuconostoc carnosum sp. nov. from chill-stored meats. Int J Syst Bacteriol 39, 217-223.

Smibert, R. M. \& Krieg, N. R. (1994). Phenotypic characterization. In Methods for General and Molecular Bacteriology, pp. 607-654. Edited by P. Gerhardt, R. Murray, W. A. Wood \& N. R. Krieg. Washington, DC: American Society for Microbiology.

Tamaoka, J. \& Komagata, K. (1984). Determination of DNA base composition by reverse-phase high-performance liquid chromatography. FEMS Microbiol Lett 25, 125-128. 